YEARBOOK
of ANTITRUST
and REGULATORY
STUDIES
www.yars.wz.uw.edu.pl

Peer-reviewed scientific periodical, focusing on legal and economic issues of antitrust and regulation. Creative Commons Attribution-No Derivative Works 3.0 Poland License.

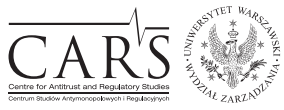

Centre for Antitrust and Regulatory Studies, University of Warsaw, Faculty of Management www.cars.wZ.uw.edu.pl

\title{
Life after Menarini: The Conformity of the Hungarian Competition Law Enforcement System with Human Rights Principles
}

\author{
by
}

Tihamér Tóth*

\section{CONTENTS}

I. Introduction

II. Competition law enforcement and judicial review in Hungary

III. Human rights invoked by undertakings in administrative proceedings

IV. Competition law cases involving human rights issues

V. The quest for finding the meaning of full judicial review: administrative discretion, deference and the prohibition of judicial reconsideration

VI. Conclusion: the conformity of the Hungarian competition law enforcement mechanism with human rights requirements

\begin{abstract}
The corporate human rights development was fueled by the increasing amount of fines imposed on both European and national level. For many years, the jurisprudence of the ECtHR has classified administrative, including competition law enforcement as a quasi-criminal process during which human rights shall be respected to a certain extent. This paper strives to explain the evolution of competition law enforcement in Hungary, with procedural safeguards protecting undertakings having come close to the level of protection provided under criminal law. Of the numerous human rights relevant in competition law enforcement the
\end{abstract}

* Professor at Pázmány Péter Catholic University, Faculty of Law and of counsel at Dentons Réczicza Europe LLP; the author benefited from its experience as a former chairman of the Competition Council of the GVH, the Hungarian competition authority; e-mail: Tihamer.Toth@dentons.com. The author would like to thank Petra Láncos, András Kovács, Pál Szilágyi and Wouter Wils for their valuable comments. Article received: 22 August 2018; accepted 30 September 2018. 
paper will focus on institutional check-and-balances, and the appropriate level of judicial review. The thoroughness of the judicial review of administrative decisions resulting in fines is critical to the analysis of whether the traditional continental European structure of administrative law enforcement is in conformity with the principles of the ECHR. The narrow interpretation of the prohibition of judicial re-evaluation and judicial deference to competition authorities exhibiting significant expert knowledge is of central importance in this debate.

\section{Résumé}

Le développement des droits de l'homme liés aux entreprises a été alimenté par le nombre croissant d'amendes imposées aux niveaux européen et national. Pendant de nombreuses années, la jurisprudence de la Cour européenne des droits de l'homme a classé le processus administratif, y compris l'application du droit de la concurrence, parmi les procédures quasi pénales au cours desquelles les droits de l'homme doivent être respectés dans une certaine mesure. Cet article vise à expliquer l'évolution de l'application des lois de la concurrence en Hongrie, considérant que les garanties procédurales protégeant les entreprises se rapprochent du niveau de protection prévu par le droit pénal. Parmi les nombreux droits de l'homme pertinents dans le domaine de l'application du droit de la concurrence, le document se concentrera sur les aspects institutionnels et sur le niveau approprié de contrôle juridictionnel. La minutie du contrôle juridictionnel des décisions administratives entraînant des amendes est essentielle pour analyser la conformité de la structure traditionnelle de l'application de la loi administrative de l'Europe continentale aux principes de la Cour européenne des droits de l'homme. L'interprétation restrictive de l'interdiction de la réévaluation judiciaire et de la retenue judiciaire à l'égard des autorités de la concurrence faisant preuve de connaissances approfondies revêt une grande importance dans ce débat.

Key words: human rights; competition law enforcement at national level; the Hungarian Competition Authority; judicial deference; administrative judicial review; fines.

JEL: K23

\section{Introduction}

European and national antitrust rules are enforced in various procedural settings. Competitors or buyers may sue cartel members or a dominant undertaking for damages before civil courts. In these cases civil procedural rules apply, plaintiffs often benefit from special provisions promoting private 
actions, i.e. rules on the presumption of damages. ${ }^{1}$ Yet, the dominant form of enforcement in Europe is public interest driven. The process is managed by expert competition authorities integrated into public administration and enjoying various degrees of independence from the government. The third, ultima ratio option is provided by criminal law. In Hungary, just like in many European countries, public prosecutors may charge directors or other persons involved in a public procurement cartel. The sentence can be imprisonment up to five years. When criminal authorities go after an individual manager or employee, criminal procedural rules with numerous and well established safeguards will apply, including the right to remain silent. General legal principles, now enshrined in constitutions, international treaties, and the EU Charter of Fundamental Rights ${ }^{2}$ protect presumably innocent persons against the potential intrusion of the State. Ever increasing antitrust fines imposed by competition authorities and accompanying 'public blame' campaigns have brought traditional administrative law enforcement closer to criminal procedures. The European Convention of Human Rights (hereinafter: ECHR) and the European Court of Justice (hereinafter: ECJ) have implanted more and more criminal law principles into administrative law. Nowadays, in many cases, authorities and attorneys spend more time on procedural issues, analyzing and developing human rights based arguments than substantial questions about the existence of a cartel.

In Hungary, ever since 1991 competition rules have been enforced by the Hungarian Competition Authority (officially: Gazdasági Versenyhivatal, hereinafter: GVH). The usual sanction is fines imposed on corporations. The procedural framework is an administrative one, the rights and obligations of the GVH and the undertakings are set out in general in the law on administrative procedures and specifically in the competition act (Act on the prohibition of unfair market practices and competition restriction, hereinafter: Tpvt.). Although the GVH investigates the actions of undertakings instead of natural persons, and sanctions may not include the restriction of personal

1 Article 17 (2) of Directive 2014/104/EU of the European Parliament and of the Council of 26 November 2014 on certain rules governing actions for damages under national law for infringements of the competition law provisions of the Member States and of the European Union, OJ L 349/1 05.12.2014.

2 The Lisbon Treaty, which entered into force on 1 December 2009, created in Article 6(2) TEU the legal basis for the EU to accede to the ECHR. According to Article 6(1) TEU, the Charter of Fundamental Rights of the EU shall have the same legal value as the Treaties. Moreover, its provisions shall be interpreted so as to guarantee at least the same level of fundamental rights protection as the ECHR. This implies that EU Courts shall take into account the case law of the Strasbourg court. This was an important development since the ECJ was reluctant to acknowledge the criminal nature of the EU Commission's antitrust procedures. 
liberty, over the years, principles rooted in criminal law have found their way into administrative procedures.

This paper strives to contribute towards explaining this evolution, focusing on institutional check-and-balances and the appropriate level of judicial review. The 'criminalization of administrative procedures' may be gleaned from the detailed procedural provisions of the Tpvt. (i.e. rules on attorney-client privilege were codified for the first time in the Tpvt., just like provisions on dawn raids and the handling of electronic evidence), but more importantly, also from the changing attitude of law enforcement and judges reviewing the GVH's decisions. Fifteen years ago, arguments based on the ECHR and the case-law of the European Court of Human Rights (hereinafter: ECtHR) were summarily dismissed. By now, the procedural safeguards protecting undertakings have come close to the level of protection provided under criminal law. Furthermore, ECHR based arguments asserted by lawyers representing alleged cartel members have become more elaborate, as did the reasoning of administrative and judicial decisions. This earlier ignorance of Strasbourg case law in antitrust proceedings was also due to the lack of understanding of the ECHR by lawyers practicing competition law, both in the authority and attorneys.

The corporate human rights development was fueled by the increasing amount of fines imposed on both European and national level, the judgments of the ECtHR classifying administrative competition law enforcement as a quasi-criminal process, and the wealth of scholarly literature, often generated by practicing attorneys drawing their experience from representing alleged cartel members before and against competition agencies. ${ }^{3}$ There is a changing public perception surrounding the stigma of being involved in a cartel emerging as a further factor contributing towards the criminalization of competition law. Although a 2006 amendment of the Criminal Code deemed public procurement cartels to be an offense in Hungary, thorough empirical research should be carried out to ascertain to what extent society considers restrictions on competition, especially cartels and abuses of a dominant position, to be a harmful act bearing a criminal, or quasi-criminal stigma. ${ }^{4}$ It is

3 The phenomenon of soft criminalization of administrative law enforcement is not peculiar to competition law. Indeed, seminal cases decided by the European Court of Human Rights involved tax law related sanctions. Many other legal fields, including administrative rules protecting the environment, could be natural candidates for human rights defenses. Actually, the largest ever fine imposed on a single undertaking in Hungary related to an environmental law infringement, also followed by criminal convictions (HUF 135 billion [EUR 421 million] was imposed on Magyar Aluminium in 2011).

${ }^{4}$ A research conducted in November 2011 by the Competition Law Research Center of the Pázmány Péter Catholic University showed that the most deterrent sanction is, first, the potential of a jail sentence for bid rigging cartels, the second would be individual administrative 
difficult to recall stories about companies being boycotted by their customers or that directors or CEOs were dismissed because of their wrongdoings. Antitrust infringements simply do not carry the same stigma as robbery, or even a theft. The devil in cartels may seem obvious only to competition law experts. The price premium consumers pay while being unaware of the cartel, or the misery of potential consumers who cannot buy the overpriced product, look more like theoretical arguments than obvious facts. It does not help either that competition authorities do not prove the upward price effect during their investigations and decisions published do not identify the harm caused. Published calculations about the theft-like price effects of cartels are prepared ex-post based on general information; they serve mainly policy purposes of competition authorities, to make sure that their existence is not questioned by populist politicians.

In this paper I will structure my thoughts as follows. First, the legal provisions on the architecture of the GVH and the role of review courts will be presented. After that, I will summarize those provisions of the ECHR which are relevant for antitrust procedures. The special focus of this paper will be on the right to an independent and fair trial, including both the administrative side of the status of the GVH and its decision making body, the Competition Council, including the depth of review carried out by administrative courts. Third, I will recall the first GVH cases at the beginning of the new millennium that dealt with human rights issues. After 2000 , following an amendment of the GVH, the establishment of a new cartel department, the hiring of case handlers with investigation experience, and a more aggressive fining policy 5 pursued by the Competition Council of the GVH, the stakes of antitrust procedures became much higher. As a result, the first references to the ECHR appeared in the arguments of the undertakings involved in cartel investigations. The next section of the paper focuses on the depth of judicial review, with special regard to the review of discretionary decisions. The thoroughness of the judicial review of administrative decisions resulting in fines is critical to the analysis of whether the traditional continental European structure of administrative law enforcement is in conformity with the principles of the ECHR. Finally, I will summarize why the present system of law enforcement is in line with the

penalties (which do not exist in Hungary), third comes corporate fines of up to $10 \%$ of the turnover and director disqualification (which does not exist either). $71 \%$ of the companies being fined reported that they put more emphasis on compliance (52 persons, mainly corporate lawyers and attorneys responded to the fairly long questionnaire).

5 This is not to claim that high fines were unknown before. There were some cases in the '90s when the Competition Council imposed high fines. Yet, these were isolated decisions, overall, the level of fines was far from having a genuine deterrent effect. 
requirements of the ECHR as well a further legal instruments with similar requirements, including the Fundamental Law (the constitution) of Hungary.

\section{Competition law enforcement and judicial review in Hungary}

The GVH conducts various procedures, some of which may result in infringement decisions with fines of up to $10 \%$ of the undertaking's turnover. About one third of all decisions handed down each year concern mergers and acquisitions. These procedures, based upon notifications submitted by undertakings, are quite different from antitrust cases. Procedural guarantees do not have an important role to play here; rather, companies seek an approval from the competition authority as soon as possible. It is also unlikely that an antitrust investigation terminated after accepting commitments proposed by companies should give rise to human rights concerns. ${ }^{6}$ Finally, just like the Polish, the Dutch or the Italian competition watchdogs, the GVH also deals with unfair commercial practices that potentially affect competition. ${ }^{7}$ Interestingly, even though the same provisions regarding fines apply here, and there are cases indeed where fines amount to tens if not hundreds of millions of HUF, or are set at the maximum level allowed by law, human rights concerns rarely if ever have arisen in misleading advertising procedures.

The GVH was established in 1990 as an independent institution reporting to the Parliament. Antitrust investigations into cartels and abuses of a dominant position start with an order issued by a case handler who is supervised by one of the vice-presidents of the $\mathrm{GVH}$, nevertheless she or he enjoys much freedom in conducting the investigation phase of the procedure. ${ }^{8}$ After several months (in a worst case scenario, after one or two years), case handlers conclude their investigation producing a report which they hand over, together with all the files of the case, to the Competition Council. The chairman of the Council appoints then a panel of three or five members of the Council. Members of the Competition Council are high level civil servants enjoying judge like independence when it comes to decision making. The proceeding competition council drafts a preliminary position, just like the EU Commission's statement of objections, to give parties the chance to defend their cases both in writing and orally. Parties have a couple of weeks

${ }^{6}$ In theory, they may or should, since commitments are born in infringement procedures, and although they are officially voluntary, undertakings are forced to act this way to avoid the bad publicity of an infringement decision as well as follow-up damage actions.

7 Actually, these procedures account for about half of the decisions each year.

8 The Legal Service department of the GVH. 
to prepare their submission and to ask for a hearing. This hearing is conducted by the chair of the proceeding council. I should mention that in the early years of competition law enforcement these hearing were just like trials in courts, the council acting like a panel of judges, the case handlers like prosecutors and the companies like defendants. Due to efficiency reasons, this system changed. Nowadays hearings are not controversial in nature, according to our experience they do not provide much added value to the written submissions, the council members rarely take an active role in bombarding the companies with questions and comments. Nowadays, the decision is adopted after the hearing and delivered to the parties. ${ }^{9}$

Parties have 30 days to file their claims before the first instance review court. Judges reviewing administrative decisions, including those of the GVH, form a special division within the given court dealing with administrative law cases. ${ }^{10}$ The judgment of the first instance court could be appealed before the Municipal Court of Law. Both courts reviewed the facts and legal questions of the cases. The first instance court routinely heard the same witnesses as the GVH. Finally, if there was a genuine legal issue disputed by the parties, they can submit an extraordinary appeal to the Curia, the highest judicial authority, where judges specialized in administrative cases hear competition law cases. ${ }^{11}$ The court system responsible for reviewing administrative decisions is in a process of transformation right now. New procedural laws will enter into force in January 2019, ${ }^{12}$ and there are plans to establish a new supreme court dedicated to administrative law, which would take over the existing duties of the Curia. Competition decisions will be reviewed by the Municipal Court of Law, which was previously the second instance court. With two, instead of the previous three court levels, final review is expected to take less time than previously.

For the sake of completeness, the role of the Constitutional Court should also be mentioned. The Constitutional Court is not part of the judicial system. Among others, it may review judgments if the constitutional rights of the parties are claimed to have been infringed. It will be shown that the

${ }^{9}$ Previously, the operative part of a final decision was adopted and read to the participants of the hearing with a short explanation at the end of the hearing, often recorded by the media, just like in court houses. The written version of the decision was delivered some weeks later.

10 They also hear labor law cases.

11 A report about administrative justice in Hungary, written by Péter Darák, the president of the Curia, can be found at http://www.aca-europe.eu/en/eurtour/i/countries/hungary/hungary_ en.pdf. See also András Kovács and Márton Varjú: Hungary: the Europeanization of judicial review, http://real.mtak.hu/19916/1/theeuropeanizationofjudicialreviewhungaryepl.pdf.

12 The new Administrative Court Procedural Act was adopted by the Parliament in February 2017. The new act, together with the new Administrative Procedural Act applicable from 1 January 2018, re-regulates judicial control of administrative procedures. 
Constitutional Court had the opportunity to rule on various human rights issues where it followed the Strasbourg jurisprudence. Relevant provisions of the Fundamental Law include Article XXIV paragraph 1 of the Chapter on 'Freedom and responsibility' providing that every person has the right to have his or her case decided by administrative authorities in a reasonable time in an impartial and fair procedure. ${ }^{13}$ The right to a fair judicial process is enshrined in Article XXVIII paragraph 1 of the Fundamental Law as the right to have criminal charges against a person or civil rights and obligations determined within a reasonable period of time in a fair and open trial by an independent and impartial court established by law. Paragraphs (2) and (4) incorporate the principles of nullum crimen sine lege and nulla poena sine lege. The similarity of these provisions entails that when the Constitutional Court interprets these provisions of the Fundamental Law, it will take into account the relevant jurisprudence of the ECtHR. ${ }^{14}$

\section{Human rights invoked by undertakings in administrative proceedings}

Originally, first generation human rights intended to protect the individual against the power of the State. These rights were gradually extended to cover less hard core aspects of human dignity, involving for example social rights. Corporations appeared on this stage in two ways. First, there is a tendency of assigning large, mainly multinational corporations the same obligations as States have to bear. ${ }^{15}$ Second, corporations also appeared as right holders. ${ }^{16}$ By now, most, if not all human rights have been acknowledged by the ECtHR to be applicable to companies as well. It is beyond doubt that despite the obvious difference between a natural and a fictional legal person, most due process related rights should be respected by public authorities when they proceed in a criminal or quasi-criminal manner against corporations. What is not entirely

13 This principle of fair administration is also incorporated into the provisions of Act 2004: CXL on Administrative Procedures.

14 See, 30/2014. (IX. 30.) AB of September 23, 2014, § 25.

15 See the UN Guiding Principles on Business and Human Rights issued in 2011, available at: https://www.ohchr.org/Documents/Issues/Business/Intro_Guiding_PrinciplesBusinessHR.pdf.

16 For a critical review of this extension of the personal scope of human rights, see: SanchezGraells, Albert and Marcos, Francisco, 'Human Rights' Protection for Corporate Antitrust Defendants: Are We Not Going Overboard? (February 2, 2014). University of Leicester School of Law Research Paper No. 14-04. Available at SSRN: https://ssrn.com/abstract $=2389715$ (noting that this trend is questioned only by a few scholars. Referring to U.S. case law on the religious freedom of corporations, they recall that this extension occurred uncritically, giving way to rather unimaginable arguments and situations). 
clear is to what extent these originally human rights should be applied in quasi-criminal procedures, involving public antitrust enforcement. ${ }^{17}$ The most recent EU legislative document, the ECN+ proposal also emphasizes the importance of human rights, and among them the right to a judicial review. ${ }^{18}$ This proposal includes provisions on procedural safeguards and the calculation of fines, yet it does not intend to harmonize the way in which judicial review of administrative decisions is organized in EU Member States.

Article 6(1) ECHR provides that 'in the determination of his civil rights and obligations or of any criminal charge against him, everyone is entitled to a fair and public hearing within a reasonable time by an independent and impartial tribunal.' Antitrust proceedings involving the imposition of a fine, concern 'criminal charges' within the wider, autonomous concept of Article 6 ECHR, even if such proceedings are not classified as criminal under domestic laws. Article 47 of the Charter implemented the protection afforded by Article 6(1) ECHR in EU law. ${ }^{19}$

17 Take, for example, the right against self-incrimination. This is a well-established principle of criminal law, but there is no global consensus as to what extent it should apply to legal entities, especially in an antitrust framework. In the U.S., this right is not acknowledged for corporations, not even in a criminal context. Also in Germany, the Bundesverfassungsgericht refused to accept this right for companies (BVerG. 26 February 1997, 1 BvR 2172/96). See in more detail, Wouter Wils: Self-incrimination in EC Antitrust Enforcement: A Legal and Economic Analysis, (2003) 26 World Competition 567. Another example can be the protection of home under Article $8 \mathrm{ECHR}$. It is extended to cover business premises too, but public authorities may interfere with this right more broadly than for private homes of natural persons (opinion of AG Geelhoed in case C-301/04 P Commission v SGL Carbon, paragraphs 62-67).

18 Proposal for a directive of the European Parliament and of the Council to empower the competition authorities of the Member States to be more effective enforcers and to ensure the proper functioning of the internal market, Brussels, 22.03.2017 COM(2017) 142 final. On page 13, it provides that 'The proposal ensures the protection of the fundamental rights of companies which are subject to competition proceedings, namely (but not exclusively), the right to conduct a business, the right to property, good administration and the right to an effective remedy before a tribunal (Articles 16, 17, 41 and 47 of the Charter of Fundamental Rights of the European Union)..... It will oblige Member States to provide for appropriate safeguards for the exercise of these powers which at least meet the standards of the Charter of Fundamental Rights of the European Union and are in accordance with general principles of EU law, including due respect of the data protection rights of natural persons. In particular, these safeguards should respect the rights of defence of companies subject to proceedings for the enforcement of Articles 101 and 102 TFEU, an essential component of which is the right to be heard. This includes the right to formal notification of the NCA's objections under EU competition law and effective right of access to the file so that companies can prepare their defence. Moreover the addresses of final decisions of NCAs applying Articles 101 and 102 TFEU should have the right to an effective remedy before a tribunal to challenge these decisions.' Available at: http://ec.europa.eu/competition/antitrust/proposed_directive_en.pdf

19 There are other ECHR provisions that may be relevant in the course of an administrative competition supervision procedure. 
Article 6(1) ECHR sets out three institutional and procedural requirements to ensure due process. First, parties should have a right to a fair and public hearing where they can explain their case. Second, all this should be arranged within a reasonable time. These two procedural requirements have not posed real issues in Hungary. Companies do have the right to argue their case orally before the decision of the Competition Council is handed down. Some antitrust investigations might take two-three years, but none of these have ever made a judge quash a 'late-comer' decision. The third requirement is that the hearing should be conducted and the decision should be delivered by an independent and impartial tribunal. This paper focuses on this third criterion.

The most important cases where the ECtHR interpreted Article 6(1) ECHR are the Engel, ${ }^{20}$ Jussila $^{21}$, Bendonoun ${ }^{22}$, and the Menarini cases. ${ }^{23}$ In Engel, the ECtHR established three criteria for evaluating the meaning of a criminal charge. These criteria, or more precisely, features of a criminal charge, are not cumulative and do not have the same weight either. First, it is relevant whether domestic law treats the contested penalties as forming a part of criminal law. If so, it is most likely that it falls under Article 6(1) ECHR. If not, the administrative or other charge can nevertheless be characterized as criminal for the purposes of the ECHR. Second, the nature of the offence should be of general concern and application. Third, the nature of the severity of the potential penalty is also important. These rather general and vague conditions were extended in Bendonoun, where the ECtHR emphasized also the importance of whether the sanction operates as punishment and/or a deterrent or much rather as a pecuniary compensation for the damage caused.

In Jussila, involving oral hearing related issues of a Finish tax administrative fine, the ECtHR, tempering the effect of its wide interpretation of the criminal charge, introduced the notions of hard core and non-hard core criminal spheres. Unfortunately, the Court neither explained how exactly the dividing line should be drawn, nor made the effects of this distinction specific. The Court noted that the criminal-head guarantees, laid down in Article 6 ECHR, do not necessarily apply with their full stringency to cases falling outside the hard core of criminal law. The court emphasized in Jussila that there are

20 Engel and Others v. the Netherlands, judgment of 8 June 1976, Series A no. 22, pp. 34-35, $\S \S 82-83$.

21 Judgment of 23 November 2006 in Jussila v Finland (Application no. 73053/01).

22 Bendonoun v France, judgment of 24 February 1994 ECtHR (A284).

23 Judgment of 27 September 2011 in Menarini Diagnostics v Italy (Application no. 43509/08). For a critical review of the Menarini judgment, see Pál Szilágyi: Fundamental rights protection and competition law in the European Union: an effects based protection and a need for reform? Published by CreatSpace, First edition (29 June 2014). 
criminal cases which do not carry any significant degree of stigma: there are clearly 'criminal charges' of differing weight and, consequently, the criminalhead guarantees did not necessarily apply with their full stringency. ${ }^{24}$

As far as the organization of the enforcement system is concerned, the ECtHR did not use Article 6 to torpedo the traditional continental administrative model which combines investigation with decision making, and often leads to the imposition of serious sanctions. However, if the sanction is imposed by a non-judicial authority, the appeal court should exercise 'full jurisdiction, including the power to quash in all respects, on questions of fact and of law, the challenged decision. ${ }^{25}$ In Jussila, the ECtHR expressly mentioned competition law declaring that severe sanctions may bring it within the 'criminal charge' box under Article 6(1) ECHR.

This reference to competition law in Jussila had been preceded by Societe Stenuit ${ }^{26}$, where the Strasbourg judges acknowledged for the first time that the procedure of the French competition authority was criminal in nature. ${ }^{27}$ Before Menarini, one could have argued in light of the exceptionally severe fines imposed, as well as the constant effort of competition authorities to present cartel members as evil, that competition law could even become part of hard core criminal charges, requiring a complete reform of the traditional European enforcement systems. ${ }^{28}$ However, the case of Kammerer ${ }^{29}$ decided in 2010, suggested that fines imposed by authorities do not carry any significant degree of stigma. By contrast, prison sentences do stigmatize and so any attempt by the administration to impose prison sentences would still fall foul of the fair trial requirement of Article 6(1) ECHR. Since companies cannot be sent to prison, administrative fines imposed on them, short of the stigma effect, would not be considered a hard core criminal sanction.

The first case where the ECtHR dealt with the substance of the architecture of traditional European competition law enforcement was Menarini. In this case, concerning an Italian cartel on the market of diagnostic tests for diabetes,

24 Jussila, para 43.

25 Jussila, para 43.

26 Societe Stenuit v. France, Judgment of 27 February 1992 ECtHR Series A No.232-A.

27 In another case, involving Russian competition law, the Court denied the applicability of Article 6(1) ECHR, given the limited scope of the act and the lack of severe sanctions. Neste $v$ Russia, Judgment of 3 June 2004 (admissibility decision in re applications no 69042/01 et al).

${ }^{28}$ Marco Bronckers and Anne Vallery: Fair and Effective Competition Policy in the EU, August 2012 European Competition Journal. Also the EFTA Court noted in April 2012 in the Posten Norge case that the fine of some $€ 12 \mathrm{~m}$ imposed by the EFTA Surveillance Authority in an abuse of dominance case carried significant stigma with it.

${ }^{29}$ Kammerer v. Austria, Judgment of 10 May 2010, No., 32435/06. The case involved a $€ 72$ fine order under the Motor Vehicles Act for non-compliance with the obligations of registered owners to have their cars duly inspected. 
it was confirmed that the imposition of criminal penalties, as interpreted under the ECHR, by an administrative body is acceptable as long as this decision is subject to full review by an independent court. The ECtHR in Menarini specified that this judicial body must have the power to annul in all respects, on questions of fact and law, the decision of the competition authority. What the ECtHR checks is whether the reviewing court in fact exercised this full jurisdiction. This was crucial in the Menarini case, since Italian review courts at that time did not have such a wide jurisdiction. ${ }^{30}$

Other relevant human rights provisions of the ECHR include Article 6(2) ${ }^{31}$, the presumption of innocence is often referred to by undertakings when it comes to uncertainties of proving a cartel. Article 8 protecting private life and home can be invoked to challenge dawn raids conducted by competition authorities. ${ }^{32}$ The principles of nullum crimen sine lege and nulla poena sine lege of Article 7 have not yet been applied in a cartel case by the ECtHR, but the Court of Justice of the European Union has already acknowledged the applicability of these principles in cartel cases. ${ }^{33}$

\section{Competition law cases involving human rights issues}

The first case I can recall where the relevance of human rights was considered by the Competition Council was the seminal motorway construction cartel. ${ }^{34}$ I had the privilege to chair the five member council in this public procurement case imposing record breaking fines in July 2004. ${ }^{35}$

However, this was not the first case where the Competition Council made reference to the jurisprudence of the ECHR. Two years earlier, in 2002, the proceeding panel of the council led by the then chairman of the Council, Barna

30 This issue was highlighted by the Hungarian judge, András Sajó, in his concurring opinion.

31 Article 48 (1) of the Charter.

32 Article 7 of the Charter. See, among others, DEBÚT Zrt. and Others v. Hungary, application no. 24851/10, decision of 20 November 2012 (refusing the complaint, emphasizing that business premises require a lower level of protection than private homes).

33 As noted by the Constitutional Court, ibid, 97., referring to C-3/06. P Groupe Danone v. Commission, ECR 2007., I-1331., 87-88.

$34 \mathrm{VJ}-27 / 2003$ Motorway construction cartel. It was especially the lawyer of the Hungarian subsidiary of the French Colas group who built his defense on procedural flaws recalling the jurisprudence of the ECHR.

35 In those days, this was the first time that a public authority would impose fines of the magnitude of billions of HUF. The case also enjoyed wide media coverage. Planning the publicity of the decision took almost as much time as deliberating on the merits of the case. The Competition Council usually hears cases in three-member panels. The chairman of the Competition Council may assign five members to important cases. 
Berke, had claimed that the Council duly respects the procedural guarantees stemming from Article 6 ECHR in the course of its infringement procedures. ${ }^{36}$ This decision acknowledged that competition supervision procedures may come under the criminal heading of Article 6 ECHR. ${ }^{37}$ The reasoning noted that the protection of human rights may also benefit corporations. ${ }^{38}$

Coming back to the motorway construction cartel case, the reasoning of this decision devoted a separate chapter to human right issues. ${ }^{39}$ It was argued that Article 6 ECHR is infringed if the authority conducting the investigation and imposing the fine is not independent. The Competition Council invoked the Albert and Le Compte, and the Van Leuven and De Meyere cases ${ }^{40}$, where the ECHR made it clear that it is sufficient if the guarantees of Article 6 are respected during the court review process of an administrative decision. The Competition Council explained that the Hungarian civil procedure code complies with these requirements. Judicial review is independent, non-biased, fair and public. Furthermore, the courts exercise full jurisdiction since they can not only annul the decisions of the GVH, but they can also amend them. Administrative courts, acting within the confines of the plaintiff's request for review, check not only the facts, but also the considerations and the discretionary powers exercised by the GVH. ${ }^{41}$

The Council was convinced that Hungarian procedural rules meet the test set out by several judgments of the European Court of Human Rights,

36 Vj-190/2001 Diákhitel Központ (Center for Student Loans), p. 10. Interestingly, the decision terminated the procedure, so the reference to human rights was not really necessary.

37 In the reasoning of the decision, no explicit reference was made to relevant cases of the European Court of Human Rights.

38 The application of the ECHR to corporations is far from evident. Furthermore, the level of protection granted to corporations may differ from those applicable to natural persons. For instance, the European Court of Human Rights held that the protection of the home provided for under Article 8 ECHR may also cover business premises, it has noted that public authorities' interference with this right might be more far-reaching where professional or business activities or premises were involved. By now, it is beyond doubt that corporations not only enjoy certain 'human' rights, but in turn, must also respect those rights.

${ }^{39}$ I can recall that this was the first time that the GVH commissioned a report by a scholar of international law, Prof. László Blutman (University of Szeged) to better understand the case-law of the European Court of Human Rights. The reasoning of the GVH decision expressly refers to the paper of Wouter P.J. Wils.: The Combination of the Investigative and Prosecutorial Function and Adjudicative Function in EC Antitrust Enforcement: A Legal and Economic Analysis (World Competition 2004 27(2), page 209) to explain that not only the Hungarian, but also the European enforcement system is in line with the ECHR.

${ }^{40}$ Van Leuven and De Meyere v Belgium, decision of 23.06.1981, point 51. Albert and Le Compte v Belgium, decision of 10.02.1983, point 29.

${ }_{11}$ The decision refers to the following judgments: Fővárosi Bíróság 2.K. 35.262/2000/8., Legfelsőbb Bíróság Kf. IV. 27.929/1998/4., Fővárosi Bíróság 2. K. 31586/1993/6. 
including the Kingsley case. ${ }^{42}$ Alternatively, it also explained that the arguments of the parties are unfounded under the ECHR anyway. The fact that the Competition Council adopting the final decision on behalf of the GVH also issues a preliminary position which summarizes the facts and the legal issues, inviting parties to explain their positions, is not contrary to the requirement of independence. Rather, it allows undertakings to exercise their rights of defense effectively. The subsequent court judgment confirmed the GVH decision. ${ }^{43}$

The Curia summarized its opinion on human rights issues in the Railways construction cartel case. ${ }^{44}$ The GVH imposed fines totaling more than HUF 7 billion in June 2010. ${ }^{45}$ Although the first instance court refused to accept the arguments of the parties based on the ECHR, it annulled the decision, arguing that the cartel was insufficiently substantiated, since all the evidence was provided by a single undertaking. The second instance court quashed that judgment, upholding the GVH decision. The Curia basically agreed with the findings of the second instance court. This case also shows that judges conduct a thorough review of cartel decisions, often arriving at different conclusions themselves.

The Curia recalled that if the Engel criteria are fulfilled, the procedure must be regarded as criminal for the purposes of the ECHR. ${ }^{46}$ Although the ECHR jurisprudence acknowledges the existence of the margin of appreciation of administrative authorities, this cannot be an explanation for a lax judicial review of antitrust fines. The takeaway form Menarini for the Curia was that a court should have the authority to review both questions of fact and law, be able to modify the decision, and be prepared to consider the principle of proportionality. The requirement of full review may even lead to the non-application of Section 339/B of the Code of Civil Procedure, that is often interpreted as precluding judicial reconsideration of discretionary administrative decisions. ${ }^{47}$ Importantly, the Charter's identical provisions form part of EU law, thus the supremacy of EU law requires national judges to put aside national laws, such as the provision of the Code of Civil Procedure that would hinder the application of EU law. ${ }^{48}$ The five-member judicial panel led by Judge Kovács found, in line with Menarini, that even if the courts referred to Section $339 / \mathrm{B}$, in effect they exercised a full review of the factual and legal issues. These statements were limited only to those procedures where

\footnotetext{
${ }^{42}$ Kingsley v United Kingdom, decision of 07.11.2000., point 58.

43 Judgments 2. K.33024/2004/46, 2.Kf. 27.360/2006/29.

44 Kfv.III.37.690/2013/29., Judgment of 20 May 2014.

45 The GVH's procedure was started in November 2007 (Vj-174/2007).

$46 \mathrm{Ibid}$, on page 25.

47 Ibid, 26.

48 Ibid, 29.
} 
the competition authority and the review courts apply EU law, including the Charter.

Furthermore, the Curia drew the important conclusion that, in effect, decisions of the GVH should be considered as an indictment issued by a public prosecutor in a criminal law procedure. ${ }^{49}$

To me, this seminal statement means that the judges should always maintain a suspicious attitude towards the findings of the GVH and apply the in dubio pro reo principle in full.

Finally, the Curia explained that the fine, the maximum amount of which was calculated based on the turnover of the group of companies, but was addressed only to one corporation of that group - did not infringe the principle of proportionality. ${ }^{50}$ Interestingly, the Supreme Court did this ex officio, even without an express claim by the parties, to show that it does take full review seriously. ${ }^{51}$

Most recent Curia judgments represent a step backwards from this brave, human rights based full review approach manifested in the Railways construction cartel. The Early repayment home loan cartel case ${ }^{52}$ involved an information sharing agreement among almost all financial institutions in Hungary involved in providing home loans. Although the infringement period was not long, the case resulted in a record fine, HUF 9.5 billion [EUR 29,6 million], of which OTP Bank had to pay 4 billion [EUR 12 million] as it was the major player on this market. On appeal, both the first and the second instance courts agreed with the Competition Council's assessment. Although the Curia also found the existence of the cartel established, it still annulled the fines and obliged the $\mathrm{GVH}$ to recalculate them in a new procedure. Writing for the Curia, Judge Kovács reconsidered some of his earlier statements in the Railways construction cartel case, giving an interpretation which no longer makes a distinction between whether the procedure is based on national or EU competition rules.

The Curia explained that 339/B $\S$ of the Civil Procedural Code prohibits judicial reconsideration only for issues of law. Review courts should always be able to collect evidence and re-evaluate existing evidence provided in the GVH decision. ${ }^{53}$ As to the conformity of the GVH procedure with Article 6 ECHR, the Curia stressed that the administrative procedure and the follow-up

49 Ibid, 30 .

50 According to the Curia, this principle can be derived from Articles 6 and 13 ECHR and Article 47 of the Charter.

51 Nevertheless, the Curia's jurisdiction is limited by law in so far as it can review only questions of law and not those of the facts.

${ }^{52} \mathrm{Vj-}-74 / 2011$ decision of the GVH, Kfv.III.37.582/2016/16. judgment of the Curia.

53 Curia judgment, point 108. 
judicial procedure have to meet those requirements. The more fair and judicial the administrative procedure is, the less complete the court review procedure could be as far as procedural safeguards are concerned. The Curia examined the structure of the $\mathrm{GVH}$ and the conduct of the competition supervision procedure in light of the independent court or tribunal-related ECHR jurisprudence. It acknowledged that both the competition authority and the decision making members of the Competition Council act independently and that the requirement of impartiality is also met. However, the GVH procedure is not contradictory and the principle of equality of arms is not ensured. The Competition Council does not act like a judicial forum, listening to the arguments of both parties and then deciding their legal dispute based upon the facts and legal arguments presented. The Council is part of the GVH, and is involved to some extent in the case handlers' investigation, as far as it can give advice about the directions of the investigation. Moreover, it is not the report of the case handlers which is shared with the parties as a Statement of Objections, but the preliminary ruling of the proceeding competition council. Since the GVH procedure does not meet all the requirements of Article 6 ECHR, the Curia explained that the judicial review process should ensure that the legal protection envisaged under the ECHR exists. Consequently, administrative courts must be able to consider the full range of relevant facts and legal issues and shall review the decision of the GVH in a sufficiently rigorous manner considering the legality and reasonability of the decision as well as whether procedural rules were respected. ${ }^{54}$

The Curia had no doubts that the principle of full judicial review is ensured in Hungary. This does not mean, however, that judicial reconsideration should be limitless. The review court should no put itself into the place of the public authority, adopting a fresh decision. Courts are required to exercise review over an existing decision. The prohibition of reconsidering the facts of the case requires judges not to disregard the reasoning of the decision and establishing de facts of the case de novo, based upon reasons independent form the authority's views. ${ }^{55}$ The prohibition of reconsideration of facts applies thus only to the procedure conducted by the Curia, which exercises an extraordinary legal review. The Curia will quash the review court's decision only if it is obviously unreasonable, suffers from logical flaws or is not sufficiently reasoned. ${ }^{56}$

In 2014, also the Constitutional Court took a position in the debate on the application of human rights in procedures conducted by the GVH. In a judgment upholding the Curia judgment concerning the Heves county

\footnotetext{
54 126-128. points of the judgment.

55 Point 142. of the judgment.

56 Point 145. of the judgment.
} 
road construction cartel case $^{57}$, the Constitutional Court summarized the jurisprudence of the ECHR recalling Jussila, Janosevic ${ }^{58}$, Menarini and $D E B U T^{59}$. The Court's opinion, drafted by Judge Dienes-Oehm, concluded that although competition supervision procedures are criminal in nature, yet they do not belong to the hard core of criminal law, therefore, principles applicable in criminal law do not apply to their full extent. The Constitutional Court took into account that competition supervision procedures generally target companies and not individuals, and the fines imposed do not have as much of a stigma effect as typical criminal prosecutions. ${ }^{60}$ Despite this cautious statement, the Constitutional Court confirmed that the principle of in dubio pro reo is applicable also in a procedure conducted by the $\mathrm{GVH}$, not only in the judicial review process. ${ }^{61}$ This means that the standard of proof should effectively be the same as under criminal law. As to the main topic of this paper, the nature of the enforcement system and the judicial review, the Constitutional Court confirmed that administrative judges can take and review evidence themselves. ${ }^{62}$ Unfortunately, the Constitutional Court did not elaborate on the required depth of the review conducted by the administrative court. ${ }^{63}$

\section{The quest for finding the meaning of full judicial review: administrative discretion, deference and the prohibition of judicial reconsideration}

The key point of defending the traditional European administrative enforcement of cartel rules is access to independent judicial review, following the decision of the competition authority. The European Court of Human

57 Decision of the Constitutional Court No. 30/2014 (IX. 30.). The Constitutional Court acted upon the complaint of an undertaking who challenged the Curia's final judgment (Kfv. II.37.076/2012/28.) based on constitutional law grounds. About a Hungarian summary of the case see: László Bak: Alkotmányos versenyjog - a versenyfelügyeleti eljárás az Alkotmánybíróság fókuszában, Versenytükör 2014/2., 52. o.. This cartel case is also a good example to show how different courts might come to different conclusions: the first instance review courts quashed the GVH decision imposing 2,9 billion HUF (about 10 million $€$ ) fines, the appeal court agreed with this, however, the Curia annulled the judgment siding with the competition authority.

58 Janosevic v Sweden, No. 34619/97, Judgment of 21 May 2003.

59 DEBÚT v Hungary, No. 24851/10., Judgment of 20 November 2012.

60 Ibid, 61-62.

61 Ibid, at 71.

62 Ibid, at 71., referring to $\S 339 / \mathrm{A}$ and 339/B. of the Code of Civil Procedures.

63 For a critical summary about the Constitutional Court's jurisprudence see: Pál Szilágyi: Fundamental Rights in Competition Proceedings before the Constitutional Court-Still Unresolved Issues, in: Global Competition Litigation Review 9 (2), 62. 
Rights uses the term 'full jurisdiction'. The exact meaning of this requirement, and whether it must be exercised in the case at hand de facto, or whether its existence de jure is sufficient, may be up for discussion. The natural limitations of administrative judicial review compared to the civil or criminal paths, where the original decision is also made by a judge, and also the related Hungarian concept of the prohibition of reconsideration by the judge ${ }^{64}$, allowing a margin of appreciation for the authorities, should be discussed here. Given the constraints of the scope of this paper, I will focus on Hungarian jurisprudence. ${ }^{65}$

When we discuss the meaning of full review, we should bear in mind that the ECtHR itself is aware that administrative review judgments cannot be the same as a de novo judgment adopted in a civil or criminal procedure. The ECtHR explained that review courts 'do not review the merits of the decision but confine themselves to ensuring, in brief, that the authority did not act illegally, unreasonably or unfairly.' ${ }^{\circ 6}$

Not surprisingly, judge Pinto de Albuquerque, dissenting in Menarini, warned that the principle of discretionary power of the administration, as applicable in most European jurisdictions, cannot be in line with the concept of full jurisdiction. Indeed, the notions of discretionary power, legal review, and judicial deference are at the heart of the issue whether the system of traditional administrative law enforcement coupled with administrative court review is in line with Article 6 ECHR.

There are many areas where administrative agencies take decisions involving the exercise of administrative discretion, or where their findings are the result of thorough consideration of facts requiring special technical knowledge or the weighing of competing public interests. The traditional role of administrative judges does not include second guessing policy issues. What they exercise is essentially a legal review.

It should be noted at the outset that in Hungary, unlike in EU competition ${ }^{l a w}{ }^{67}$, no distinction is made between the review of the substance of the operative part of GVH decisions, that is, the existence of a cartel or a dominant position, and the review of the fines. Hungarian courts have the power to quash or amend every part of an infringement decision.

64 In Hungarian:‘a bírói felülmérlegelés tilalma'.

65 As to the case of EU courts, I find the paper by Wouter WILS particularly useful: EU Antitrust Enforcement Powers and Procedural Rights and Guarantees: The Interplay between EU Law, National Law, the Charter of Fundamental Rights of the EU and the European Convention on Human Rights, World Competition, Vol. 34, No. 2, June 2011.

66 Weeks v. UK Series A no 114 (1987); 10 EHRR 293.

67 According to Regulation 1/2003/EC EU, courts can amend only the fines imposed by the EU Commission, but not the operative part of the decision. 
The role of Hungarian administrative courts was expressly stipulated in Section 339/B of the Act on Civil Procedure: a discretionary decision should be considered lawful if the facts of the case are well established, procedural rules were observed, the factors taken into account by the authority can be identified, and the reasoning of the decision shows that the authority reasonably considered each piece of evidence..$^{68}$ The new law on administrative court proceedings adopted a new text, it is not known yet how judicial practice will evolve in the future. According to 85. $\S(5)$, in the case of legal review of discretionary decisions the court should also check whether the authority remained within the boundaries of its discretionary powers and whether the reasoning of how it arrived at its decision is clear and reasonable.

The former statutory provision resulted in a rather passive judicial activity, where some judges were reluctant to reconsider the fines unless the GVH made a legal error on the substance of the case.$^{69}$ A recent report of the Curia's working group analyzing the jurisprudence of the courts on administrative fines noted that even though Hungarian courts have full jurisdiction, they exercised their full review powers as regards fines only when the authority erred in the substance of the case as well. The report also called for the Curia to bring more clarity to the issues of judicial review of discretionary decisions in the future. ${ }^{70}$

The prohibition of judicial reconsideration of discretionary decisions is a well-established doctrine in Hungarian administrative law. Its essence is that whenever an administrative authority enjoys a room of appreciation provided by law, and it adopts a well-reasoned decision staying within this boundary, courts should withstand from judicial activism substituting their assessment for that of the authority. The rationale of this restriction can be traced back, among others, to more practical considerations such as traditional division of powers. The judicature should not take over the role of policy-making and administering regulations (A. Kovacs and M. Varju, 2014). ${ }^{71}$ Another way to describe this concept is to discuss judicial deference (Bernatt, 2014). ${ }^{72}$

68 The European Court of Justice proceeds along the same principles: 'the review of complex economic appraisals made by the Commission is necessarily limited to checking whether the relevant rules on procedure and on the stating of reasons have been complied with, whether the facts have been accurately stated and whether there has been any manifest error of assessment or a misuse of powers.' EU courts exercise a legality review under Article 263 TFEU.

${ }^{69}$ Curia judgment of Legf. Bír. Kfv.IV.37.499/2009/10.

70 November 10, 2014 (published on March 23, 2015), page 20. http:/www.lb.hu/sites/default/ files/joggyak/a_kozigazgatasi_birsagok_vizsgalati_targykorben_joggyakorlat-elemzo_csoport_ osszefoglalo_velemenye.pdf (last accessed on June 20, 2015). The Curia is entrusted with the task of monitoring the practice of lower courts to maintain the uniformity of judicial practice.

71 The authors discuss the legal foundations of administrative judicial review in Hungary.

72 Available at SSRN: https://ssrn.com/abstract=2447884 or http://dx.doi.org/10.2139/ ssrn.2447884 (concluding that the way in which the EU Courts review EU Commission 
However, unlike the prohibition of judicial reconsideration, this is not a legal principle, but more like a matter of fact.

However, when the exercise of discretionary powers could result in a tremendous amount of fines, the need for thorough judicial review arises. The traditional concept restricting reconsideration of the facts is simply not apt to antitrust investigations and other quasi criminal procedures.

In my view, this rule restricting judicial review should not be interpreted widely, implying that judges could not act effectively when plaintiffs ask them to reassess facts and law that require some economic knowledge or the consideration of forensic evidence. Truly, judges are not superheroes, but they do have access to experts and should possess the wisdom to decide on the concurring arguments of the parties. This prohibition of 'second guessing' does not render the review of the substance of cartel or abuse of dominance cases a mere formality. From time to time, there may be difficult cartel cases where the evidence is not entirely clear regarding the existence of a secret agreement, or there might be some doubt about the effects of an exclusionary behavior by a dominant undertaking.

Beyond legal concepts as well as institutional and procedural rules, a de facto crucial issue is to what extent are administrative judges overburdened. As a rule, there are no competition law specialized review courts in Europe. Administrative judges in Hungary have to proceed in various cases involving taxation, migration, environmental law, etc. Of these, competition law files occupy the most space and energy. It is not easy to exercise genuine full review under such pressure and with such a diverse focus on various legal issues related to administrative law. ${ }^{73}$

It is important that complex competition law issues (like proving a cartel based on circumstantial evidence, analyzing competition effects or making the distinction between fierce and abusive competition), and the often difficult choice among conflicting pieces of evidence, however difficult they may be to decide, do not involve the exercise of discretionary power subject to inherently limited judicial review. There is just one single correct answer to the question whether there was a cartel or not, or whether a company is dominant or not. ${ }^{74}$ Discretionary decisions should mean something else.

decisions is not very likely to be found in violation of Article 6 of the ECHR, however, further improvements of fairness of the administrative process should be considered).

73 As for EU courts reviewing EU Commission decisions, one author argued for an increase of the number of judges to ensure full review in practice; Igor Nikolic: Full judicial review of antitrust cases after KME: a new formula of review? (2012) 33 ECLR, issue 12, p. 583.

${ }^{74}$ I should admit that cases involving the consideration of facts related to future market conditions, especially in merger and acquisition procedures, may involve some administrative discretion. However, in cases like this fines are not imposed, so human rigths issues, especially those related to Article 6 ECHR are irrelevant. 
Where the GVH exercises genuine administrative discretion is only in its decisions regarding the amount of the fines. ${ }^{75}$ Acting within the boundaries of its legal mandate given by the legislature, the Competition Council can choose whatever amount it sees fit for the infringement. Moreover, the Council is not obliged to impose fines automatically - it may even decide to establish an infringement of competition rules without fining the companies. As long as the amount of the fine does not exceed the statutory ceiling, and all relevant factors are considered sufficiently and fairly, parties will have a hard time in court persuading the judge to annul or reduce the fine. This is because if the existence of a cartel is proven, the competition authority could take an unlimited number of decisions on the appropriate level of the fines, provided that it gives sufficient reasons. The same cartel participation can be fined HUF 7,9 billion, HUF 4,3 billion, HUF 989,567 million, etc. as long as it does not cross the legal maximum and the rather vaguely formulated requirement of proportionality, provided the gravity and duration of the infringement were considered by the decision maker.

From this perspective, the significance of adopting non-binding guidelines on the method of calculating fines can be appreciated. Fining guidelines enhance legal certainty, predictability, and thus contribute to the goal of deterrence. Hungarian courts did struggle with GVH guidelines, there were cases where they simply disregarded them arguing that non-binding guidelines are not sources of law, so they fall beyond the scope of their legality review. Subsequent judgments delivered by the Constitutional Court and the Supreme Court followed a path more in line with EU courts, explaining that the principle of legal certainty requires review courts to check whether the GVH complied with its own guidelines, or whether the decision sufficiently explained why it deviated from the fining guidelines (T. Tóth, 2010).

At first sight, there seems to be a contradiction here. On the one hand, I argue that the GVH enjoys wide discretion when it decides on fines. This discretion is somewhat limited by its own fining guidelines. It should follow that administrative judges should exercise some self-restraint in this respect, not putting themselves into the shoes of the competition authority by re-evaluating what fines could best serve the goals of competition law enforcement. Yet, the ECtHR requires full jurisdiction review when it comes to the imposition of significant sanctions aimed at punishing or deterring unlawful behavior. Judges

75 Administrative authorities enjoy discretionary powers only where expressly provided by statutes. For example, if the competition act reads that the GVH may impose fines of up to $10 \%$ of the undertaking's (or the group of undertakings) annual turnover, it provides discretion for the authority at three stages: $(i)$ is there a need to impose fines at all, (ii) if so, what should be the exact amount of the fine within the $10 \%$ range, and (iii) should the ceiling be set based on the turnover of the given corporation or the group of undertakings. 
are not expected to invent new ways of calculating fines 'from scratch', but should thoroughly check whether the GVH took into account all the relevant factors and afforded them the correct weight. For this purpose, as the Curia noted, the principle of proportionality should be of special importance.

This does not mean, however, that this inherently limited judicial review would not meet the full jurisdiction test of the ECtHR. Even the ECtHR takes into account when assessing the adequacy of judicial review, whether the decision subject to review involves the exercise of administrative discretion. ${ }^{76}$

The prohibition of reconsideration should not prevent a judge from carefully reviewing all claims of the parties, involving arguments on the facts of the case and the interpretation of the law, including the amount of the fines. For example, if the GVH failed to correctly establish the length of the infringement, or the role played by a cartel member, this factual error may easily lead to a recalculation and reduction of the fine. More importantly, even if the court agrees with the GVH on the facts of the case, not challenging the existence of a cartel, it should nevertheless feel competent to modify the level of the fines, namely, by invoking the general principle of proportionality. In a similar vein, a judge may consider that a repeated infringement should not lead to the automatic doubling of the fine, but should entail an increase of $50 \%$ instead, regardless of what is stipulated by the authority's fining guidelines. The prohibition of judicial reconsideration should not imply that courts can change the fines only if they also discern a factual error committed by the GVH.

Under this realistic approach towards the interpretation of full review, it would be unreasonable to expect a judge to exercise its review powers to re-calculate the fine by assigning somewhat different points to the factors taken into account by the Competition Council of the GVH. ${ }^{77}$ For example, where the GVH applied a 25 point score to describe the seriousness of the infringement, judges would not give 23 or 24 points instead. ${ }^{78}$ Such amendment of the GVH decision would hardly be justified even under the principle of proportionality.

Put it differently, the concept of full review is still about the required depth of a just review process. A review is always linked to a previous decision. It makes thus sense to consider the administrative and judicial stage in one. It is rational to argue that the thoroughness of judicial review is related to the structure and procedural guarantees of the administrative decision making process. Organizing two complete and fair hearings, both by the competition

\footnotetext{
76 Sigma Radio Television Ltd. v Cyprus (Application no, 32181/05).

77 The Competition Council calculates the amount of the fine based on a 100 points scoreboard which can be fine-tuned according to criteria like recidivism and leniency application.

78 As a matter of fact, not even plaintiffs themselves come forward with such claims.
} 
authority and later by the court would make procedures inefficient and unreasonably lengthy. I share the views of Graells and Macros, reminding us, just as the Curia did in the early repayment home loan case, that even the jurisprudence of the ECtHR supports such 'lighter' judicial review. ${ }^{79}$ The ECtHR found that where the administrative body followed a procedure which sufficiently complies with due process guarantees, and the decision involves a 'classic exercise of administrative discretion', or where the decision requires 'a measure of professional knowledge or experience and the exercise of administrative discretion pursuant to wider policy aims', then a mere review of legality complies with the ECHR, provided that the judge can quash the first instance decision. A lighter review could be accepted thus involving issues like exemption from competition rules requiring complex market knowledge, or fines reflecting a certain policy of the competition authority. Such a quasifull review can be in line with quasi-criminal cases. No deference should, however, be exercised about cartel related issues and checking whether fines comply with fundamental legal principles.

\section{Conclusion: the conformity of the Hungarian competition law enforcement mechanism with human rights requirements}

Following the Menarini judgment, it is now beyond reasonable doubt that the traditional administrative competition law enforcement system meets the requirements of Article 6(1) ECHR. According to the ECtHR, public enforcement of competition rules against companies fits well into the quasicriminal basket of cases. Even if fines can be exceptionally high, neither the subjects of competition law sanctions (typically legal persons instead of human beings), nor the seriousness of their wrongdoing (restricting free competition that may result in higher prices, lower output), nor the nature of the sanctions (pecuniary instead of limiting human freedoms) warrant a hard-core criminal approach. Put it differently, unlike individuals, companies would rarely, if ever, be stigmatized by high fines imposed on them. No one would expect customers to turn away from companies such as Google, Mercedes, LG, or Philips just because they were hit by huge fines. Ensuring the respect of procedural guarantees and due process is important so that the authority adopts good decisions. Pushing the corporate human rights argument to its extreme does not add too much to this debate.

${ }^{79}$ Ibid, at page 12. 
Consequently, an agency model that combines investigative and decisionmaking powers, including the imposition of substantial fines, does not infringe human rights of corporations, as long as these decisions are subject to review by an independent judge exercising full jurisdiction. The ECtHR does not seem to give much weight to what extent the authority is independent and acts along the lines of due process requirements, or how many levels the court review process includes. Considering cases from a practical point of view, the ECtHR looks at what review courts actually did, instead of how the national procedural provisions could be understood literally.

Given the identical structure of competition law enforcement in Italy and Hungary, and the practice of Hungarian administrative judges to go into the details of each GVH decision, including the facts, the legal interpretation and the amount of the fines imposed, parties challenging the legality of the Hungarian system of competition law enforcement before the ECtHR would not be likely to succeed, just as they failed to persuade the Hungarian Constitutional Court.

My experience talking with administrative law judges confirmed that they regard the Competition Council of the GVH as a quasi-judicial body, wellstaffed to decide complex economic and legal issues. Judges are aware that members of the Competition Council are independent, almost like judges. They cannot get orders from the government, not even from the president of the $\mathrm{GVH}$ or the chairman of the Council. ${ }^{80}$ Naturally, judges were more prone to adopt a less activist attitude, in cases where some doubt may have arisen, erring on the side of the competition agency. All this is now confirmed by the Curia's reasoning in the early repayment home loan cartel case. This does not mean, however, that review courts, including the Curia, would not exercise their full jurisdiction when it was necessary to do so. The existence of a natural judicial deference to a competent and well skilled authority does not run counter to the requirement of full review in quasi-criminal administrative procedures.

I find it interesting that the ECtHR did not elaborate in Menarini on the status of the competition authority, and the level of the protection of procedural rights in the administrative procedure; instead, the focus of its reasoning related to the level of judicial review. Contrary to this, the Hungarian Curia emphasized in the early repayment home loan cartel case that there is a link between the status and governance of the competition authority and meeting the requirements of Article 6 ECHR. In borderline cases such as the Italian Menarini case, it may be important to bear in mind to what extent the authority itself could be considered as acting independently of governmental policy. The more the administrative procedure resembles a judicial process,

${ }^{80}$ I should add that about half of the members of the first Competition Council were former civil law judges. 
the less relevant the inquiry into the sufficiency of judicial review seems to be. I would not go so far as to argue that it would be redundant, since sanctioning decisions adopted by an authority that started the procedure itself will always suffer from some level of deficit. The prosecutorial bias can be minimized with internal checks and balances, but cannot be eliminated (W. Wils, 2006) ${ }^{81}$

In sum, the judgments of the ECtHR, the Hungarian Curia and the Constitutional Court made it clear that the traditional administrative law enforcement regime is in conformity with human rights requirement. In order to ensure procedural fairness, great emphasis was put on how administrative judicial review is regulated, and more importantly, how it is exercised in real cases. It seems that even if courts do not conduct a green field litigation, in the sense that they have to rule on the legality of an administrative decision adopted following a long and thorough competition supervision procedure, Article 6 of the ECHR is not infringed as long as judges review questions of facts and law and have the power to change the fines imposed by the authority.

This is not to say that human rights related arguments in competition proceedings were and will be completely unfounded. There are some procedural issues which may cause concerns and so they should be scrutinized under the jurisprudence of the ECtHR. They include: the process of recording covert witness statements without providing an opportunity for the parties to ask questions directly, the lack of effective court review of on the spot searches ${ }^{82}$, the immediate enforceability of administrative fines ${ }^{83}$, or denying the privilege against self-incrimination ${ }^{84}$. As to Article 6(1) ECHR, the length of the procedures, including the administrative and the first instance court review phase, may become an issue were the GVH does not respect procedural deadlines. ${ }^{85}$ Yet, the system as such can work efficiently, while at

81 Discussing various potential bias during competition law procedures.

82 See the Vinci cases decided by the ECtHR criticizing the French regulation of dawn raids: Vinci Construction et GTM Génie Civil et Services c. France (63629/10). Later, in its decision of 21 March 2017, No. 33931/12 Janssen Cilag S.A.S v France, the court found the modified French regulation to be in compliance with the requirements of the ECHR.

${ }^{83}$ It is true that parties who cannot pay the fine can submit a request for suspension to the first instance court, but the court is usually reluctant to do so and cannot carry out an in-depth review anyway. So, in the vast majority of the cases, the fines should be paid. The European Court of Human Rights ruled in Janosevic that the immediate enforcement of the payment of fines may infringe the principle of the presumption of innocence.

84 The European Court of Human Rights has not addressed this issue with respect to companies yet. In the U.S., companies do not enjoy this privilege. The German Bundesverfassungsgericht also held that this privilege does not extend to legal persons, because it is grounded in the protection of individual human dignity (BVerG, 26 February 1997, 1 BvR 2172/96).

85 According to Section 63. Tpvt., cartel and abuse of dominance procedures, including two potential extensions, should not last more than one and a half years. There can be two problems 
the same time respecting the rights of corporations as required by the ECtHR jurisprudence.

\section{Literature}

Bak, L. (2014). Alkotmányos versenyjog - a versenyfelügyeleti eljárás az Alkotmánybíróság fókuszában. Versenytükör 2.

Bronckers, M. Vallery, A. (2012). Fair and Effective Competition Policy in the EU, European Competition Journal, vol. 8(2), pp. 41-57.

Bernatt, M. (2014). The Compatibility of Deferential Standard of Judicial Review in the EU Competition Proceedings with Article 6 of the European Convention on Human Rights. Institute for Consumer Antitrust Studies Working Papers, Loyola University Chicago, available at: https://ssrn.com/abstract $=2447884$.

Graells, A.S. and Marcos F. (2014). "Human rights" Protection for corporate Antitrust Defendants: Are We Not Going Overboard? University of Leicester School of Law Research Paper, No. 14-04.

Kovács, A. and Varjú, M. (2014). Hungary: The Europeanization of Judicial Review, European Public Law, vol. 20(2).

Nikolic, I. (2012). Full judicial review of antitrust cases after KME: a new formula of review? European Competition Law Review, vol. 33(12).

Szilágyi, P. (2016). Fundamental Rights in Competition Proceedings before the Constitutional Court-Still Unresolved Issues, Global Competition Litigation Review, vol. 9 (2).

Tóth, T. (2010). Az Alkotmánybíróság határozata a Gazdasági Versenyhivatal közleménykiadási jogáról, JeMa 1.

Wils, W. (2004). The Combination of the Investigative and Prosecutorial Function and Adjudicative Function in EC Antitrust Enforcement: A Legal and Economic Analysis. World Competition, vol. 27(2).

Wils, W. (2006). Optimal Antitrust Fines: Theory and Practice. World Competition, vol. 29(2).

here. First, there are lots of procedural actions that are not counted into this 18 months period (in practice, only case handlers can know how much of the time has been absorbed). Second, there is no clear legal consequence of infringing the statutory deadlines. The temptation is thus strong to conduct a thorough investigation disregarding the time limits. The total length of the procedure, including the first judgment is never shorter than 2-3 years. Even if this might not infringe human rights, an effective sanction policy would require a decision much closer in time to the unlawful action. 